\title{
Studies of the Metabolism and Distribution of Fibrinogen in Healthy Men with Autologous ${ }^{125}$ I-labeled Fibrinogen *
}

\author{
Y. TAKEDA $\dagger$ \\ (From the Department of Medicine, University of Colorado School of Medicine, Denver, Colo.)
}

A few studies of the metabolism and distribution of fibrinogen in healthy men have been reported (1-3), but because of the lability of fibrinogen and the methods employed the earlier of these do not appear to have been entirely successful. Recent advances in the preparation of fibrinogen${ }^{131} \mathrm{I}(4,5)$ and in the mathematics of its kinetic behavior (6) have made possible more reliable and extensive studies. Observations have therefore been made on 12 healthy male volunteers with autologous fibrinogen labeled with ${ }^{125} \mathrm{I}$.

\section{Methods}

The subjects, mainly graduate students or janitors, were healthy male volunteers, ranging from 16 to 54 years in age. They took 10 drops of saturated KI solution three times a day for the 3 days preceding the experiment and 10 drops once daily during the 7 to 9 days of the experiment. The preparation of fibrinogen for labeling was carried out by a minor modification of the method of Atencio, Burdick, and Reeve (4) as follows: About $20 \mathrm{ml}$ plasma, separated from the subject's heparinized blood, was diluted with an equal volume of $0.09 \mathrm{M}$ sodium citrate and recentrifuged for 10 minutes to remove any remaining platelets and red cells. The diluted plasma was mixed with $4 \mathrm{M}\left(\mathrm{NH}_{4}\right)_{2} \mathrm{SO}_{4}$ (saturated) in a volume ratio of 3 to 1 , left at room temperature for 5 minutes, and spun for 5 minutes at $2,000 \mathrm{rpm}$, and the supernatant was discarded. The precipitate, after washing three times with a total of $120 \mathrm{ml}$ of $1 \mathrm{M}\left(\mathrm{NH}_{4}\right)_{2} \mathrm{SO}_{4}$, was dissolved in $15 \mathrm{ml}$ of $0.005 \mathrm{M}$ sodium citrate, reprecipitated with $5 \mathrm{ml}$ of $4 \mathrm{M}\left(\mathrm{NH}_{4}\right)_{2} \mathrm{SO}_{4}$, and washed once

* Submitted for publication July 14, 1965 ; accepted October 6, 1965.

This work was supported by research grant HE-02262 from the National Heart Institute and stimulated by research grant FR-051 from the U. S. Public Health Service. The work was done during the tenure of an Advanced Research Fellowship of the American Heart Association.

A preliminary report was presented to the Sixteenth Autumn Meeting of the American Physiological Society.

$\dagger$ Address requests for reprints to Dr. Y. Takeda, University of Colorado Medical Center, 4200 E. Ninth Ave., Denver, Colo. 80220. with $40 \mathrm{ml} 1 \mathrm{M}\left(\mathrm{NH}_{4}\right)_{2} \mathrm{SO}_{4}$. The fibrinogen was then dissolved in $4 \mathrm{ml}$ of $0.005 \mathrm{M}$ sodium citrate, refrigerated at $4^{\circ} \mathrm{C}$ for 3 hours, and spun down at $4^{\circ} \mathrm{C}$ for 20 minutes to remove cold insoluble material. At this stage the clottability of fibrinogen was usually $95 \%$ or greater. If less than $95 \%$, the fibrinogen was reprecipitated and again washed with $1 \mathrm{M}\left(\mathrm{NH}_{4}\right)_{2} \mathrm{SO}_{4}$. The clottability was measured as described elsewhere (4). The fibrinogen was then labeled with ${ }^{125} \mathrm{I}$ in a ratio of 0.5 or less atoms iodine per molecule of fibrinogen by the iodine monochloride method $(4,5,7)$, after which free ${ }^{125} \mathrm{I}$ was removed by repeated precipitation and washing with $1 \mathrm{M}$ $\left(\mathrm{NH}_{4}\right)_{2} \mathrm{SO}_{4}$. The fibrinogen- ${ }^{125} \mathrm{I}$ was dissolved in $4 \mathrm{ml}$ of $0.005 \mathrm{M}$ sodium citrate, refrigerated for 3 hours, and centrifuged at $3,000 \mathrm{rpm}$ for 20 minutes to remove any cold insoluble material. The amount of free ${ }^{125} \mathrm{I}$ in the fibrinogen- ${ }^{125}$ I preparations was less than $1 \%$ of the total radioactivity. The preparation was sterilized by filtration through a Selas filter (FMB-52-03) 1 with a positive pressure of 5 pounds per square inch. One $\mathrm{ml}$ of 6 $\mathrm{mg}$ per $\mathrm{ml}$ human serum albumin ${ }^{2}$ in $0.005 \mathrm{M}$ sodium citrate was first passed through the filter and then the fibrinogen- ${ }^{-25} \mathrm{I}$ mixed with $1 \mathrm{ml}$ of the same albumin solution. The clottability of fibrinogen- ${ }^{125} \mathrm{I}$ did not significantly differ from that of the unlabeled fibrinogen (4).

The interval between the withdrawal of plasma for preparation of fibrinogen for labeling and the injection of fibrinogen $-{ }^{125} \mathrm{I}$ was 24 hours. Five to $15 \mu \mathrm{c}$ of fibrinogen- ${ }^{125} \mathrm{I}$ in a volume of 4 to $5 \mathrm{ml}$ containing about $5 \mathrm{mg}$ of fibrinogen was injected intravenously into the subjects. The first blood sample was withdrawn 15 minutes and subsequent samples $\frac{1}{4}, \frac{1}{2}, 1,2,3,4,5,6$, and 7 , and sometimes 8 and 9 days after the injection. Samples were heparinized. Twenty-four-hour urine collections were made daily throughout the experiments. Plasma and urine samples were assayed for radioactivity in a well scintillation counter with spectrometer and a sensitivity of about $7 \times 10^{5} \mathrm{cpm}$ per $\mu \mathrm{c}$ of ${ }^{125} \mathrm{I}$ above the background of $50 \mathrm{cpm}$. The plasma volume was obtained from the total fibrinogen-bound radioactivity injected divided by the counts per minute per milliliter plasma of the 15 -minute sample. The plasma fibrinogen concentration was measured daily by the isotope dilution method of Atencio and co-workers (4). Many plasma samples were analyzed for radioactivity unbound to fibrinogen. For this $2 \mathrm{ml}$ plasma was mixed with $1 \mathrm{ml}$ of $30 \%$ trichloroacetic acid

\footnotetext{
1 Microbiological Associates, Bethesda, Md.

2 Normal human serum albumin U.S.P., Merck Sharp \& Dohme, Philadelphia, Pa.
} 
TABLE I

Body weight and plasma data

\begin{tabular}{|c|c|c|c|c|c|c|c|}
\hline Subject & Age & Height & Weight & $\begin{array}{l}\text { Plasma } \\
\text { volume }\end{array}$ & $\begin{array}{c}\text { Plasma } \\
\text { fibrinogen }\end{array}$ & $\begin{array}{c}\text { Total } \\
\text { plasma } \\
\text { fibrinogen }\end{array}$ & Hematocrit \\
\hline & years & $\mathrm{cm}$ & $\mathrm{kg}$ & $\mathrm{ml} / \mathrm{kg}$ & $m g / m l$ & $m g / k g$ & $\%$ \\
\hline YT & 37 & 173 & 72.7 & 34.1 & 3.34 & 114 & 51 \\
\hline $\mathrm{LR}$ & 22 & 177 & 65.9 & 36.3 & 3.59 & 130 & 49 \\
\hline CJ & 26 & 179 & 69.0 & 35.0 & 3.06 & 107 & 50 \\
\hline$M M$ & 23 & 180 & 90.9 & 31.7 & 4.58 & 145 & 52 \\
\hline AT & 29 & 189 & 79.5 & 36.3 & 4.05 & 147 & 51 \\
\hline $\mathrm{BS}$ & 17 & 180 & 68.2 & 37.5 & 3.05 & 114 & 49 \\
\hline ML & 25 & 191 & 75.0 & 39.9 & 3.26 & 130 & 51 \\
\hline $\mathrm{FG}$ & 27 & 185 & 77.2 & 32.8 & 4.12 & 135 & 52 \\
\hline RU & 48 & 168 & 67.2 & 27.7 & 3.79 & 105 & 51 \\
\hline WF & 54 & 165 & 77.2 & 35.7 & 3.96 & 141 & 50 \\
\hline AP & 20 & 174 & 72.9 & 35.5 & 3.04 & 108 & 49 \\
\hline $\mathrm{CU}$ & 21 & 179 & 65.9 & 44.8 & 3.33 & 149 & 47 \\
\hline \multicolumn{2}{|c|}{$\begin{array}{l}\text { Mean } \\
\text { SD }\end{array}$} & 178 & 73.5 & $\begin{array}{r}35.6 \\
\pm 3.5\end{array}$ & $\begin{array}{r}3.60 \\
\pm 0.50\end{array}$ & $\begin{array}{r}127 \\
\pm 17\end{array}$ & $\begin{array}{r}50 \\
\pm 1\end{array}$ \\
\hline
\end{tabular}

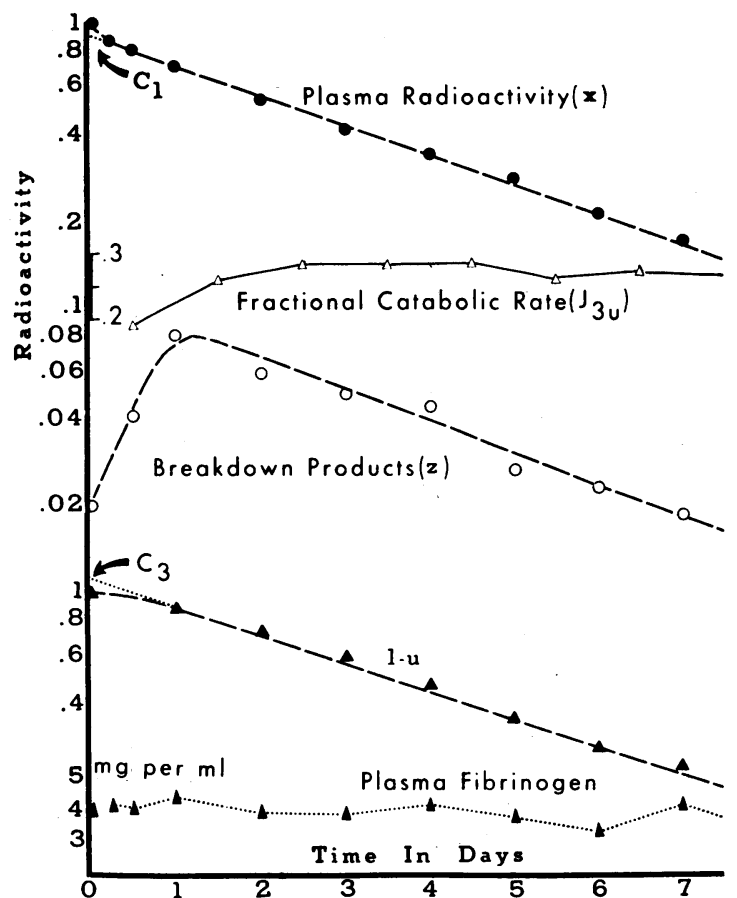

Fig. 1. IN VIVO BEHAVIOR OF IV ADMINISTERED FIBRINOGEN ${ }^{125} \mathrm{I}$ IN SUBJECT RU. $x, \mathrm{z}$, and $1-\mathrm{u}$ represent the radioactivities of the plasma fibrinogen- ${ }^{125} \mathrm{I}$, the breakdown products of fibrinogen- ${ }^{125} \mathrm{I}$ in the iodide space, and the total radioactivity remaining in the body at time $t$, respectively, and are expressed as fractions of the total radioactivity initially injected. $C_{1}$ is the intercept of the slower component of $x$ with the ordinate at zero time, and $C_{3}$ is the intercept of the $1-\mathbf{u}$ curve with the ordinate at zero time. $j_{3 u}$ is calculated from $x$ and $\mathbf{u}(6)$. The plasma fibrinogen concentrations are given in terms of milligrams per milliliter. and after refrigeration for 30 minutes spun at $3,000 \mathrm{rpm}$ for 30 minutes at $4^{\circ} \mathrm{C}$. The supernatant was assayed for radioactivity. All measured radioactivities were corrected for decay by reference to duplicate standards, prepared from dilutions of the fibrinogen- ${ }^{125} \mathrm{I}$ with nonradioactive carrier plasma in $0.9 \% \mathrm{NaCl}$. The microhematocrit was determined on all blood samples.

The mathematical model used for analysis of the data is fully described elsewhere (6). The differential equations describing the model and their solutions provide the following rate constants: the fractional catabolic rates of plasma fibrinogen $j_{3 p}$ and $j_{3 u}$ were calculated from $j_{3 p}=$ $\left(\mathrm{C}_{1} / \mathrm{a}+\mathrm{C}_{2} / \mathrm{b}\right)^{-1}$, and $j_{3 u}$ from $j_{3 u}=\mathrm{u}_{2,3} / \xi_{2,8}\left(\mathrm{t}_{3}-\mathrm{t}_{2}\right) \cdot\left(\mathrm{k}_{5}-\right.$ a) $/ k_{5}$, where $C_{1}, a, C_{2}$, and $b$ are the parameters of a function $(x)$ describing the behavior of plasma fibrinogen${ }^{125} \mathrm{I}, \mathrm{u}_{2,3}$ is the total radioactivity excreted in the urine during the time interval $t_{2}$ to $t_{3}, \xi_{2,3}$ is the mean plasma radioactivity during the same interval, and $k_{5}$ is the daily fractional excretion rate of the breakdown products of fibrinogen- ${ }^{125} \mathrm{I}$ through the kidney. Previous observations (8) showed that the mean value of $\mathrm{k}_{5}$ was 2.02 per day. The fractional transcapillary transfer rate of plasma fibrinogen $j_{1}$ was calculated from $j_{1}=\mathrm{C}_{1} \mathrm{a}+\mathrm{C}_{2} \mathrm{~b}-j_{3 p}$. The catabolic and transcapillary fibrinogen fluxes were obtained from $j_{3 p} \overline{\mathrm{x}}$ and $j_{1} \overline{\mathrm{x}}$, respectively, where $\overline{\mathrm{x}}$ is the mean total fibrinogen in the plasma. The amount of interstitial fibrinogen, $\bar{y}$, was calculated as described previously $(9,10)$.

\section{Results}

Body weight and plasma data. Table I summarizes measurements of the body weight, plasma volume, plasma fibrinogen concentration, the total plasma fibrinogen, and the hematocrit values. The plasma volume ranged from 27.7 to 44.8 with a mean value of $35.6 \mathrm{ml}$ per $\mathrm{kg}$ body weight. The hematocrit values averaged $50 \%$ with a range of 
47 to 52 . The plasma fibrinogen concentration fluctuated around the mean from day to day, and averaged $3.60 \mathrm{mg}$ per $\mathrm{ml}$ with a range of from 3.04 to 4.58 . The degree of fluctuation varied from one subject to another. It was large in some and practically undetectable in other subjects (Figure 1). The quantities of fibrinogen $(\bar{x})$ within the plasma compartment averaged $127 \mathrm{mg}$ per $\mathrm{kg}$ body weight with a range of from 105 to 149. The clottability of the fibrinogen- ${ }^{125} \mathrm{I}$ preparations varied from 95 to 98 with a mean of $96 \%$ (Table II).

The function describing the plasma fibrinogen${ }^{125} I$ radioactivity, $x$, and the cumulative excretion of radioactivity, $u$. The plasma radioactivities of all samples were expressed as fractions of the 15minute sample, and these data were analyzed by the method of least squares with the IBM 709 digital computer (11). The data were closely described by a two-exponential equation of the form, $x=\mathrm{C}_{1} \mathrm{e}^{-\mathrm{at}}+\mathrm{C}_{2} \mathrm{e}^{-\mathrm{bt}}$. The closeness of the fit is demonstrated by the small values of the "variance of the fit" (11) as given in Table II. The values for the parameters of $x$ are also given in Table II, which shows that in the 12 subjects studied the average value is $x=0.82 \mathrm{e}^{-0.207 t}+$ $0.18 \mathrm{e}^{-3.57 t}$. The results of a typical experiment are shown in Figure 1. The half-life of the slower component, a, of $x$ varied from 2.78 to 3.65 with a mean value of 3.36 days (Table II).

The cumulative urinary excretions of radioactivity in all subjects were expressed as fractions of the total radioactivity initially injected. Table III shows that the radioactivity excreted during the first 24 hours varied from 12.5 to 16.4 with a mean of $14.5 \%$ excluding subjects $\mathrm{AT}$ and WF. The total radioactivity excreted by the seventh day ranged from 63.5 to 82.2 with a mean of $72.5 \%$. In subject $\mathrm{YT}$ the total radioactivity excreted amounted to $89.5 \%$ by the ninth day. A typical

TABLE II

Tracer data on the in vivo behavior of fibrinogen-125I and the calculated rate constants*

\begin{tabular}{|c|c|c|c|c|c|c|c|c|c|c|}
\hline \multirow[b]{2}{*}{ Subject } & \multirow{2}{*}{$\begin{array}{c}\text { Clottabil- } \\
\text { ity of fi- } \\
\text { brinogen--125I }\end{array}$} & \multicolumn{4}{|c|}{$x=\mathrm{C}_{1} \mathrm{e}^{-\mathrm{at}}+\mathrm{C}_{2} \mathrm{e}^{-\mathrm{bt}}$} & \multirow[b]{2}{*}{$\mathrm{s}^{2}$} & \multirow[b]{2}{*}{$t_{1}$ for $a$} & \multirow[b]{2}{*}{$j_{1}$} & \multirow[b]{2}{*}{$j_{8 p}$} & \multirow[b]{2}{*}{$j_{3 u}$} \\
\hline & & $\mathrm{C}_{1}$ & a & $\mathrm{C}_{2}$ & b & & & & & \\
\hline & $\%$ & & & & & & days & $d a y^{-1}$ & $d a y^{-1}$ & $d a y^{-1}$ \\
\hline YT & 95 & $\begin{array}{c}0.89 \\
+0.01 \dagger\end{array}$ & $\begin{array}{r}0.200 \\
\pm 0.004\end{array}$ & $\begin{array}{r}0.11 \\
+0.01\end{array}$ & $\begin{array}{r}2.39 \\
+0.00\end{array}$ & $1 \times 10^{-4}$ & 3.47 & 0.219 & 0.222 & 0.242 \\
\hline LR & 95 & $\begin{array}{r}0.77 \\
\pm 0.02\end{array}$ & $\begin{array}{r}0.201 \\
\pm 0.006\end{array}$ & $\begin{array}{r}0.23 \\
\pm 0.02\end{array}$ & $\begin{array}{r}2.68 \\
\pm 0.41\end{array}$ & $8 \times 10^{-5}$ & 3.45 & 0.515 & 0.256 & 0.265 \\
\hline CJ & 98 & $\begin{array}{r}0.83 \\
\pm 0.04\end{array}$ & $\begin{array}{r}0.214 \\
\pm 0.010\end{array}$ & $\begin{array}{r} \pm 0.17 \\
0.17 \\
\pm 0.04\end{array}$ & $\begin{array}{r} \pm 0.41 \\
3.61 \\
\pm 1.96\end{array}$ & $5 \times 10^{-4}$ & 3.24 & 0.540 & 0.251 & 0.250 \\
\hline $\mathbf{M M}$ & 97 & $\begin{array}{r}0.76 \\
\pm 0.01\end{array}$ & $\begin{array}{r}0.198 \\
\pm 0.005\end{array}$ & $\begin{array}{r}0.24 \\
\pm 0.01\end{array}$ & $\begin{array}{r}3.12 \\
\pm 0.33\end{array}$ & $5 \times 10^{-5}$ & 3.50 & 0.644 & 0.255 & 0.237 \\
\hline AT & 98 & $\begin{array}{r}0.83 \\
0.81 \\
\pm 0.01\end{array}$ & $\begin{array}{r}0.220 \\
\pm 0.005\end{array}$ & $\begin{array}{r}0.17 \\
\pm 0.01\end{array}$ & $\begin{array}{r}3.89 \\
+0.69\end{array}$ & $7 \times 10^{-5}$ & 3.15 & 0.582 & 0.262 & $\ddagger$ \\
\hline BS & 95 & $\begin{array}{r}0.84 \\
\pm 0.01\end{array}$ & $\begin{array}{r}0.249 \\
\pm 0.005\end{array}$ & $\begin{array}{r}0.16 \\
\pm 0.01\end{array}$ & $\begin{array}{r}9.26 \\
\pm 3.24\end{array}$ & $8 \times 10^{-5}$ & 2.78 & 1.394 & 0.295 & 0.295 \\
\hline ML & 96 & $\begin{array}{r}0.82 \\
+0.05\end{array}$ & $\begin{array}{r}0.190 \\
\pm 0.01\end{array}$ & $\begin{array}{r}0.18 \\
\pm 0.05\end{array}$ & $\begin{array}{r}2.10 \\
+0.82\end{array}$ & $3 \times 10^{-4}$ & 3.65 & 0.307 & 0.227 & 0.202 \\
\hline FG & 95 & $\begin{array}{r}0.80 \\
\pm 0.05\end{array}$ & $\begin{array}{c}0.203 \\
\pm 0.01\end{array}$ & $\begin{array}{r}0.20 \\
\pm 0.05\end{array}$ & $\begin{array}{r}2.11 \\
\pm 0.84\end{array}$ & $3 \times 10^{-4}$ & 3.41 & 0.333 & 0.251 & 0.232 \\
\hline $\mathrm{RU}$ & 95 & $\begin{array}{r}0.82 \\
\pm 0.03\end{array}$ & $\begin{array}{r}0.220 \\
+0.01\end{array}$ & $\begin{array}{r}0.18 \\
\pm 0.03\end{array}$ & $\begin{array}{r}2.30 \\
\pm 0.65\end{array}$ & $2 \times 10^{-4}$ & 3.15 & 0.372 & 0.222 & 0.252 \\
\hline WF & 96 & $\begin{array}{r}0.87 \\
\pm 0.02\end{array}$ & $\begin{array}{r}0.206 \\
\pm 0.008\end{array}$ & $\begin{array}{r}0.13 \\
\pm 0.02\end{array}$ & $\begin{array}{r}5.68 \\
\pm 2.72\end{array}$ & $2 \times 10^{-4}$ & 3.36 & 0.682 & 0.236 & $\ddagger$ \\
\hline AP & 95 & $\begin{array}{r}0.79 \\
+0.01\end{array}$ & $\begin{array}{r}0.190 \\
+0.006\end{array}$ & $\begin{array}{r}0.21 \\
+0.01\end{array}$ & $\begin{array}{r}3.59 \\
+0.49\end{array}$ & $9 \times 10^{-5}$ & 3.65 & 0.667 & 0.237 & 0.227 \\
\hline $\mathrm{CU}$ & 97 & $\begin{array}{r}0.82 \\
\pm 0.02\end{array}$ & $\begin{array}{r}0.196 \\
\pm 0.008\end{array}$ & $\begin{array}{r}0.18 \\
\pm 0.02\end{array}$ & $\begin{array}{r}2.13 \\
\pm 0.49\end{array}$ & $1 \times 10^{-4}$ & 3.54 & 0.320 & 0.234 & 0.219 \\
\hline Mean & 96 & $\begin{array}{r}0.82 \\
\pm 0.02\end{array}$ & $\begin{array}{r}0.207 \\
\pm 0.007\end{array}$ & $\begin{array}{r}0.18 \\
\pm 0.02\end{array}$ & $\begin{array}{r}3.67 \\
\pm 1.16\end{array}$ & $1 \times 10^{-4}$ & $\begin{array}{r}3.36 \\
\pm 0.25\end{array}$ & $\begin{array}{r}0.548 \\
\pm 0.309\end{array}$ & $\begin{array}{r}0.246 \\
\pm 0.016\end{array}$ & $\begin{array}{r}0.242 \\
\pm 0.026\end{array}$ \\
\hline
\end{tabular}

* In the two-exponential equation, $x=\mathrm{C}_{1} \mathrm{e}^{-\mathrm{at}}+\mathrm{C}_{2} \mathrm{e}^{-\mathrm{bt}}, \mathrm{C}_{1}$, a, $\mathrm{C}_{2}$, and $\mathrm{b}$ are parameters of the function of time ( $\mathrm{t}$ ) describing the behavior of plasma fibrinogen-125 $; t_{1}$ is the half-life of the slower component, a, of $x$. $j_{1}$ is the fractional transcapillary transfer rate of plasma fibrinogen per day. $j_{3 p}$ and $j_{3 u}$ are the fractional catabolic rates of plasma fibrin-" ogen per day. $j_{3 p}$ is calculated from $x$ and $j_{3 u}$ from $x$ and the urinary radioactivity (6). $\mathrm{s}^{2}$ is the "variance of the fit" (11).

† Standard deviation.

$\ddagger j_{3 u}$ values were not calculated for subjects AT and WF because their urine collections were inadequate. 
TABLE III

Cumulative urinary excretion of radioactivity $(u)$ expressed as fractions of the total radioactivity injected*

\begin{tabular}{|c|c|c|c|c|c|c|c|c|c|c|c|c|}
\hline \multirow[b]{2}{*}{ Subject } & \multirow[b]{2}{*}{$\mathrm{C}_{3}$} & \multirow[b]{2}{*}{$a_{u}$} & \multirow[b]{2}{*}{$\mathrm{s}^{2}$} & \multicolumn{9}{|c|}{ Days } \\
\hline & & & & 1 & 2 & 3 & 4 & 5 & 6 & 7 & 8 & 9 \\
\hline $\mathrm{YT}$ & $\begin{array}{c}1.10 \\
\pm 0.02 \dagger\end{array}$ & $\begin{array}{r}0.239 \\
\pm 0.006\end{array}$ & $2 \times 10^{-4}$ & 0.150 & 0.306 & 0.453 & 0.570 & 0.655 & 0.738 & 0.801 & 0.846 & 0.895 \\
\hline LR & $\begin{array}{r}1.06 \\
+0.01\end{array}$ & $\begin{array}{r}0.212 \\
+0.002\end{array}$ & $3 \times 10^{-5}$ & 0.146 & 0.297 & 0.434 & 0.541 & 0.631 & 0.701 & 0.766 & & \\
\hline CJ & $\begin{array}{r}1.03 \\
+0.01\end{array}$ & $\begin{array}{r}0.201 \\
+0.003\end{array}$ & $4 \times 10^{-5}$ & 0.164 & 0.306 & 0.439 & 0.548 & 0.619 & 0.688 & 0.753 & & \\
\hline MM & $\begin{array}{r}1.00 \\
\pm 0.02\end{array}$ & $\begin{array}{r}0.168 \\
+0.005\end{array}$ & $2 \times 10^{-4}$ & 0.157 & 0.309 & 0.414 & 0.508 & 0.581 & 0.641 & 0.677 & & \\
\hline $\begin{array}{l}\mathrm{AT} \ddagger \\
\mathrm{BS}\end{array}$ & $\begin{array}{r}1.08 \\
+0.01\end{array}$ & $\begin{array}{r}0.253 \\
+0.002\end{array}$ & $1 \times 10^{-5}$ & $\begin{array}{l}0.136 \\
0.158\end{array}$ & $\begin{array}{l}0.256 \\
0.344\end{array}$ & $\begin{array}{l}0.346 \\
0.490\end{array}$ & $\begin{array}{l}0.423 \\
0.603\end{array}$ & $\begin{array}{l}0.496 \\
0.691\end{array}$ & $\begin{array}{l}0.542 \\
0.761\end{array}$ & $\begin{array}{l}0.602 \\
0.822\end{array}$ & & \\
\hline ML & $\begin{array}{r}1.00 \\
\pm 0.01\end{array}$ & $\begin{array}{r}0.180 \\
\pm 0.003\end{array}$ & $9 \times 10^{-5}$ & 0.138 & 0.275 & 0.375 & 0.454 & 0.524 & 0.592 & 0.635 & & \\
\hline FG & $\begin{array}{r}1.02 \\
\pm 0.01\end{array}$ & $\begin{array}{r}0.172 \\
\pm 0.003\end{array}$ & $5 \times 10^{-5}$ & 0.130 & 0.280 & 0.382 & 0.478 & 0.569 & 0.634 & 0.693 & & \\
\hline $\mathrm{RU}$ & $\begin{array}{r}1.08 \\
\pm 0.01\end{array}$ & $\begin{array}{r}0.209 \\
\pm 0.003\end{array}$ & $8 \times 10^{-5}$ & 0.125 & 0.278 & 0.421 & 0.540 & 0.630 & 0.689 & 0.739 & & \\
\hline $\begin{array}{l}\text { WF } \ddagger \\
\text { AP }\end{array}$ & $\begin{array}{r}1.00 \\
\pm 0.02\end{array}$ & $\begin{array}{r}0.173 \\
\pm 0.006\end{array}$ & $2 \times 10^{-4}$ & $\begin{array}{l}0.052 \\
0.144\end{array}$ & $\begin{array}{l}0.152 \\
0.312\end{array}$ & $\begin{array}{l}0.238 \\
0.405\end{array}$ & $\begin{array}{l}0.278 \\
0.488\end{array}$ & $\begin{array}{l}0.329 \\
0.590\end{array}$ & $\begin{array}{l}0.360 \\
0.646\end{array}$ & $\begin{array}{l}0.392 \\
0.688\end{array}$ & & \\
\hline $\mathrm{CU}$ & $\begin{array}{r}1.01 \\
\pm 0.02\end{array}$ & $\begin{array}{r}0.158 \\
\pm 0.007\end{array}$ & $4 \times 10^{-4}$ & 0.137 & 0.290 & 0.359 & 0.437 & 0.556 & 0.610 & 0.677 & & \\
\hline Mean & $\begin{array}{r}1.04 \\
\pm 0.02\end{array}$ & $\begin{array}{r}0.197 \\
+0.004\end{array}$ & $1 \times 10^{-4}$ & 0.145 & 0.300 & 0.417 & 0.516 & 0.605 & 0.671 & 0.725 & 0.846 & 0.875 \\
\hline
\end{tabular}

* $\mathrm{C}_{3}$ is the intercept of the $1-\mathrm{u}$ curve with the ordinate at zero time. $a_{u}$ is the rate of decline per day of the $1-u$ curve. $s^{2}$ is the "variance of the fit" (11).

$\dagger$ Standard deviation.

¥ Calculations were not made in subjects AT and WF because their urine collections were inadequate.

urinary radioactivity curve is shown in Figure 1. When 1 minus the cumulative urinary excretion of radioactivity, $u$, is plotted against time, after a day or two in all experiments $1-\mathbf{u}$ is described by the exponential curve $1-\mathfrak{u}=\mathrm{C}_{3} \mathrm{e}^{-\mathrm{aut}}$. The parameters $C_{3}$ and $a_{u}$ were determined by the method of least squares by the IBM 709 digital computer (11). The values of $C_{3}, a_{u}$, and "the variance of the fit" are given in Table III, which demonstrates that observed $1-\mathfrak{u}$ is closely fitted by the exponential equation $1-\mathfrak{u}=\mathrm{C}_{3} \mathrm{e}^{-\mathrm{aut}}$.

The radioactivity unbound to fibrinogen in the $b o d y, z$. This radioactivity was calculated from the counts per minute per milliliter of the supernatant from plasma treated with trichloroacetic acid and corrected for the dilution by the trichloroacetic acid and distribution in the iodide space. The latter was taken as $31 \%$ of body weight (8). The radioactivity so calculated was expressed as a fraction of the total radioactivity injected. A typical $z$ curve is shown in Figure 1. Mean values for $\mathrm{z}$ with their standard deviations for seven subjects at $0, \frac{1}{4}, \frac{1}{2}, 1,2,3,4,5,6$, and 7 days after injection of fibrinogen- ${ }^{125} \mathrm{I}$ were $0.02 \pm 0.01$,
$0.03 \pm 0.01,0.05 \pm 0.02,0.09 \pm 0.03,0.08 \pm 0.01$, $0.05 \pm 0.01,0.05 \pm 0.01,0.04 \pm 0.01,0.03 \pm 0.01$, and $0.03 \pm 0.01$, respectively. Thus $z$ rises rapidly, reaches its maximal value on the first day, and thereafter declines at an exponential rate, paralleling the rate of decline of the plasma fibrinogen- ${ }^{125}$ I radioactivity. However, the radioactivity unbound to fibrinogen in the plasma never exceeded $2 \%$ of the total plasma fibrinogen radioactivity.

Calculation of the fractional rates and fibrinogen fluxes. It was shown by Atencio, Bailey, and Reeve (6) that whether or not the animal fibrinogen system was in a steady state, as evidenced by fluctuations or lack of fluctuations of plasma fibrinogen concentration, the fractional rates for fibrinogen breakdown and transcapillary transfer and fibrinogen fluxes could be calculated from the tracer data provided these showed certain characteristics. First, the plasma fibrinogen- ${ }^{125} \mathrm{I}$ radioactivity $x$ must be described by an exponential equation of the form $x=\mathrm{C}_{1} \mathrm{e}^{-\mathrm{at}}+\mathrm{C}_{2} \mathrm{e}^{\mathrm{bt}}$; second, after a day or two the curve describing $1-\mathrm{u}$ must be described by an exponential equation of the 
form $1-\mathrm{u}=\mathrm{C}_{3} \mathrm{e}^{-\mathrm{aut}}$ with $\mathrm{a}_{\mathrm{u}}$ close in numerical value to a. Further characteristics are that the data describing the downslope of the $z$ curve should be described by $z=C_{z} e^{-a_{z} t}$ and that $a_{z}$ should also be close to a. Another requirement is that the observed values of $1-u, z$, and the extravascular fibrinogen radioactivity $(y)$ should closely agree with those predicted by the model of fibrinogen metabolism (6). Table II demonstrates that the plasma fibrinogen- ${ }^{125} \mathrm{I}$ data are well fitted by a two-exponential curve and Table III that $1-$ $\mathfrak{u}$ is closely fitted by a single exponential curve. Further, the Tables show that $a$ and $a_{u}$ are very near in magnitude, the mean value for a being 0.207 and for $a_{u} 0.197$ in the subjects in whom valid comparisons can be made. This agreement is excellent considering the inherent errors in urinary collection and the possibilities of loss of ${ }^{125} \mathrm{I}$ through sites other than the urine (12). Analysis of the data for $z$ shows that the mean value for $a_{z}$ is 0.198 , which is very near the mean value for a in the same subjects. Also, it was seen, as discussed later, that the observed values of $1-\mathrm{u}, \mathrm{z}$, and $\mathrm{y}$ agreed very closely with those predicted by the model (6). It is therefore concluded that fibrinogen- ${ }^{125} \mathrm{I}$ in man and rabbit behaves very similarly and the same kinetic analysis may be applied to both. The equations used for calculating the fractional rates and fibrinogen fluxes are given in the Methods, and more fully elsewhere (6).
The fractional rates, $j_{1}$ and $j_{3}$, and the fibrinogen fluxes, $j_{1} \bar{x}$ and $j_{3} \bar{x}$. Table II shows that the fraction of plasma fibrinogen filtered through the capillaries per day, $j_{1}$, averaged 0.548 with a range of from 0.219 to 1.394 , and the fraction of plasma fibrinogen catabolized per day, $j_{3 p}$, ranged from 0.222 to 0.295 with a mean value of 0.246 per day. The fractional catabolic rate calculated from $x$ and the urinary radioactivity, $j_{3}$, averaged 0.242 per day with a range of 0.202 to 0.295 and is in close agreement with $j_{3 p}$. The transcapillary fibrinogen flux, $j_{1} \bar{x}$, ranged from 24.9 to 159.4 with a mean value of $69.0 \mathrm{mg}$ per $\mathrm{kg}$ body weight per day. The catabolic flux, $j_{3} \bar{x}$, averaged $31.3 \mathrm{mg}$ per $\mathrm{kg}$ per day with a range of from 23.3 to 38.5 (Table IV).

Interstitial fibrinogen, $\bar{y}$, and its passage time distribution through the interstitial fluids, $F(T)$. Elsewhere $(9,10)$ the interstitial albumin is pictured as flowing through an innumerable number of tubes with varying passage times, and the passage time distribution $[\mathrm{F}(\mathrm{T})]$ of these tubes, namely that of interstitial albumin, is derived with the plasma albumin specific activity curve. This being the case, the total amount of interstitial albumin can be calculated from $j_{1} \bar{x} \int_{0}^{\infty} \mathrm{F}(\mathrm{T}) \mathrm{dT}$, where $j_{1} \overline{\mathbf{x}}$ is the inflow of albumin into the interstitial fluids $(9,10)$. By these methods the interstitial fibrinogen $\bar{y}$ was calculated, which averaged $24.0 \mathrm{mg}$ per $\mathrm{kg}$ body weight with a range of from

TABLE IV

Fibrinogen fluxes and interstitial fibrinogen*

\begin{tabular}{|c|c|c|c|c|c|c|}
\hline Subject & $j_{1} \overline{\mathbf{x}}$ & $j_{3 p p \bar{x}}$ & $\overline{\mathbf{y}}$ & $\bar{y} / \bar{x}$ & $F(T) \underset{d}{=} e^{-d T}$ & \\
\hline & $\mathrm{mg} / \mathrm{day} / \mathrm{kg}$ & $\mathrm{mg} / \mathrm{day} / \mathrm{kg}$ & $m g / k g$ & & & \\
\hline YT & 24.9 & 25.3 & 11.6 & 0.102 & 2.15 & \\
\hline LR & 67.1 & 33.4 & 31.8 & 0.244 & 2.11 & \\
\hline $\mathrm{CJ}$ & 57.8 & 26.9 & 19.1 & 0.178 & 3.03 & \\
\hline MM & 93.5 & 37.0 & 38.6 & 0.266 & 2.42 & . \\
\hline $\mathrm{AT}$ & 85.5 & 38.5 & 26.2 & 0.178 & 3.27 & \\
\hline BS & 159.4 & 33.7 & 20.3 & 0.178 & 7.82 & \\
\hline ML & 39.9 & 29.5 & 22.8 & 0.175 & 1.75 & \\
\hline $\mathrm{FG}$ & 45.0 & 33.9 & 25.9 & 0.192 & 1.73 & \\
\hline $\mathrm{RU}$ & 39.1 & 23.3 & 20.3 & 0.193 & 1.93 & \\
\hline WF & 96.4 & 33.4 & 19.4 & 0.137 & 4.97 & \\
\hline $\mathrm{AP}$ & 71.9 & 25.6 & 25.0 & 0.232 & 2.88 & $\therefore$ \\
\hline $\mathrm{CU}$ & 47.7 & 34.9 & 26.9 & 0.180 & 1.78 & \\
\hline $\begin{array}{c}\text { Mean } \\
\text { SD }\end{array}$ & $\begin{array}{r}69.0 \\
\pm 35.3\end{array}$ & $\begin{array}{r}31.3 \\
\pm 5.0\end{array}$ & $\begin{array}{r}24.0 \\
\pm 6.8\end{array}$ & $\begin{array}{r}0.188 \\
\pm 0.044\end{array}$ & $\begin{array}{r}2.99 \\
\pm 1.78\end{array}$ & \\
\hline
\end{tabular}

* $j_{1} \overline{\mathrm{x}}$ is the amount of intravascular fibrinogen filtered through the capillaries per day. $j_{3 p} \overline{\bar{x}}$ is the amount of intravascular fibrinogen catabolized per day. $\overline{\mathrm{y}}$ is the interstitial fibrinogen. $\overline{\mathrm{y}} / \overline{\mathrm{x}}$ is the ratio of the interstitial to the intravascular fibrinogen. $\mathrm{F}(\mathrm{T})$ is the function describing the passage time distribution of interstitial fibrinogen. 
11.6 to 38.6. The ratio of the interstitial to the intravascular fibrinogen ranged from 0.102 to 0.266 with a mean value of 0.188 (Table IV). When the plasma fibrinogen radioactivity curve is a two-exponential function, the passage time distribution of $\bar{y}$ through the interstitial fluids is a single exponential function, $\mathrm{F}(\mathrm{T})=\mathrm{e}^{-\mathrm{d} \mathrm{T}}(9,10)$, and Table IV shows that $\mathrm{d}$ varied from 1.73 to 7.82 with a mean value of 2.99 . The values of $F\left(T_{1}\right)$ for a given value of $T_{1}$ represent the fraction of the transcapillary fibrinogen flux, $j_{1} \bar{x}$, that requires a passage time greater than $T_{1}$ to pass through the interstitial fluids $(9,10)$. The calculation showed that on the average $30 \%$ of the fibrinogen influx returned to the vascular system in $\frac{1}{8}$ day after entry, $49 \%$ by $\frac{1}{4}$ day, $72 \%$ by $\frac{1}{2}$ day, $84 \%$ by $\frac{3}{4}$ day, and $90 \%$ by 1 day. However, the calculation of the fraction of $\bar{y}$ that requires passage times through the interstitial fluids greater than $\frac{1}{8}, \frac{1}{4}, \frac{1}{2}$, $\frac{3}{4}$, and 1 day $(9,10)$ showed that they were 94 , $83,60,43$, and $29 \%$, respectively. Thus, the major part of the fibrinogen flux passes rapidly through the interstitial fluids, but the major fraction of the interstitial fibrinogen is in slower passage through the interstitial fluids.

\section{Discussion}

The present studies were carried out in residents of Denver at an altitude of 5,280 feet. The average plasma fibrinogen concentration was $3.60 \pm 0.5$ $\mathrm{mg}$ per $\mathrm{ml}$. This is considerably higher than the average value of $2.5 \mathrm{mg}$ per $\mathrm{ml}$ for residents at sea level (13). The isotope dilution method used for making the measurements has been thoroughly studied elsewhere (4), and the raised plasma fibrinogen levels in healthy Denver residents have been confirmed by another method (13).

The user of iodinated proteins for metabolic studies always has to provide evidence that the iodination has not altered the metabolism of the protein. In animal experiments comparisons can be made with proteins "biologically" labeled (5) or with "screened" proteins (5), but this is not possible in man. The following arguments, however, indicate that the ${ }^{125}$ I-labeled fibrinogens used were satisfactory. Preparations made in similar circumstances $(3,14)$ behave satisfactorily in rabbits. The fibrinogen preparations averaged $96 \%$ in clottability, and ultracentrifugal analysis (Figure 2) showed a high degree of purity. Protein denaturation leads to lowered values of

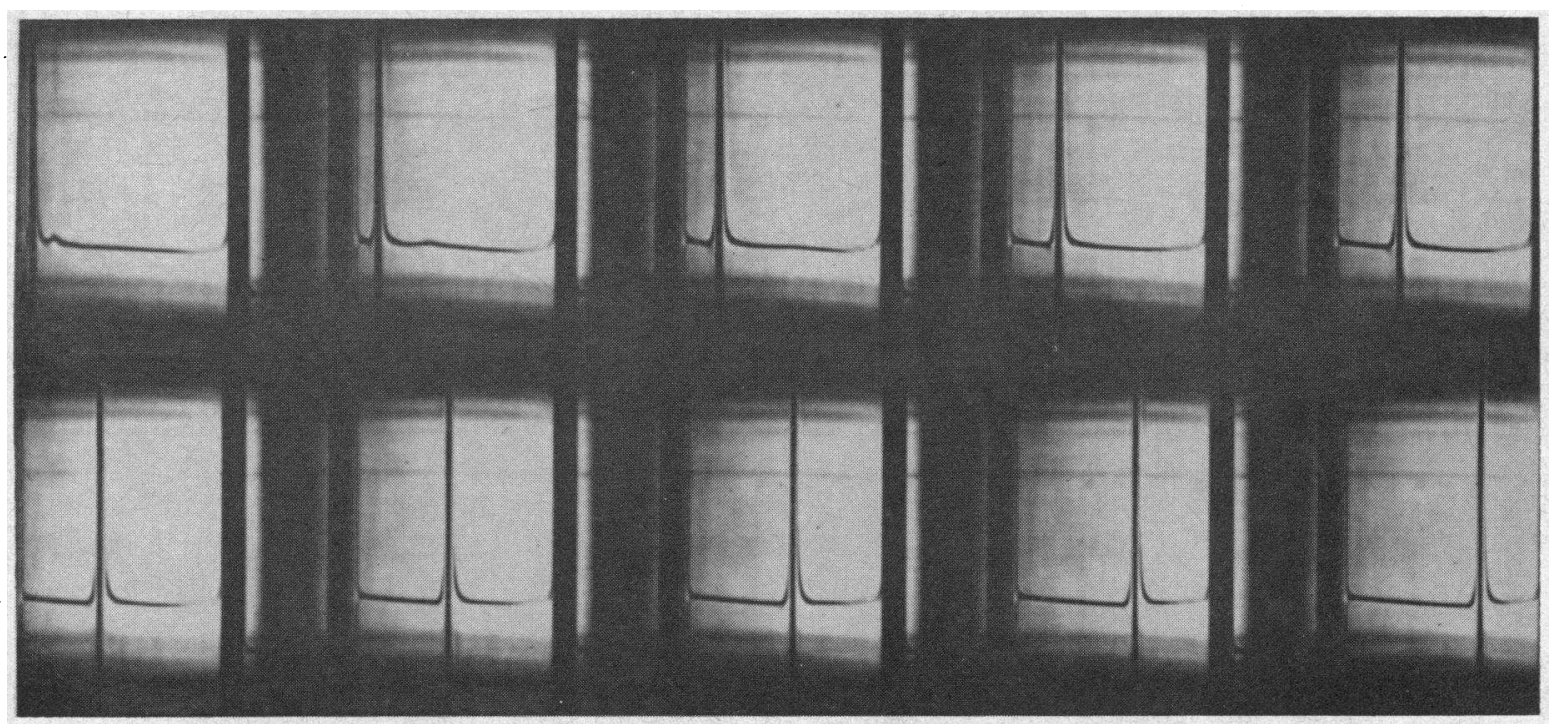

Fig. 2. Ultracentrifugal patterns of the fibrinogen preparation. The fibrinogen analyzed was $95 \%$ clottable with a concentration of $1.2 \mathrm{~g}$ per $100 \mathrm{ml}$. The solvent was $0.005 \mathrm{M}$ sodium citrate. The analysis was carried out in a Spinco model $\mathrm{E}$ ultracentrifuge at $59,780 \mathrm{rpm}$ and $20^{\circ} \mathrm{C}$. The pictures were taken at 8-minute intervals (from left to right) for the total period of 80 minutes. There are small amounts of impurities in the first and second pictures. The calculation showed that the sedimentation coefficient of the impurity was 37.2 , which is much greater than 7.63 for fibrinogen. 
$\mathrm{C}_{1}$, early accumulation of free ${ }^{125} \mathrm{I}$ in the plasma with resulting high $\mathrm{z}$ values, and early urinary excretion of ${ }^{125} \mathrm{I}$ at an increased rate (15). None of these findings were seen in the present study. $\mathrm{C}_{1}$ averaged the high value of 0.82 (Table II), plasma free ${ }^{125} \mathrm{I}$ never exceeded $2 \%$ of the total plasma fibrinogen radioactivity, and $j_{3 u}$, which is equivalent to Berson's degradation rate (15), was minimal during the first day and thereafter remained constant (Figure 1). Another test may be used with the fibrinogen- ${ }^{125} \mathrm{I}$. It has been claimed that plasma volume measured with fibrinogen- ${ }^{125} \mathrm{I}$ is significantly less than when measured with albumin- ${ }^{-131} \mathrm{I}$ (16). Fibrinogen- ${ }^{131} \mathrm{I}$ that gives higher values for plasma volume than albumin${ }^{131}$ I may therefore be considered questionable in conjunction with our unpublished observations. In the present study plasma volume measured with fibrinogen- ${ }^{125} \mathrm{I}$ averaged $35.6 \mathrm{ml}$ per $\mathrm{kg}$ body weight and was significantly less $(.05>\mathrm{p}>.02)$ than the average value of $38.3 \mathrm{ml}$ per $\mathrm{kg}$ obtained with albumin- ${ }^{131} \mathrm{I}$ on a similar group of subjects in a previous study (10).

Previous studies using fibrinogen- ${ }^{131} \mathrm{I}$ and other methods have reported varying results. Madden and Gould (1) reported a study of fibrinogen metabolism in three presumably healthy subjects using ${ }^{35} \mathrm{~S}$-labeled amino acids and gave a mean halflife of 5.6 days. Volwiler and his associates (2) also made a study in eight healthy subjects using ${ }^{35} \mathrm{~S}$-labeled amino acids and gave a mean half-life of 3.5 days. Half-lives alone are insufficient to define fibrinogen metabolism. Gitlin and Borges (17) reported studies on two children with congenital afibrinogenemia in whom they injected nonradioactive fibrinogen intravenously and followed its behavior in the plasma immunochemically. They found about 0.5 for $\mathrm{C}_{1}$ and a mean half-life of 4 days. However, the metabolism of a plasma protein in a subject congenitally lacking it may not reflect its metabolism in a normal subject. Christensen (18), Hammond and Verel (19), and MacFarlane, Todd, and Cromwell (3) have published studies of fibrinogen metabolism in healthy and sick subjects using fibrinogen- ${ }^{131} \mathrm{I}$, but in some of the studies signs of denaturation of the fibrinogen-131I preparations seem more or less evident. Thus, Christensen gave about 0.5 for the average value of $C_{1}$ and a mean half-life of 4.3 days in subjects suffering from headache, neurosis, neurasthenia, gastritis, epilepsy, or asthenia. Hammond and Verel reported about 0.45 for the average value of $C_{1}$ and a mean half-life of 5.1 days in six patients, and their fibrinogen- ${ }^{131} \mathrm{I}$ gave much higher values of plasma volume than those obtained with albumin${ }^{131} \mathrm{I}$. The long half-lives suggest the presence of labeled globulins, since altered fibrinogen-131 I does not show an increased half-life (6). The fibrinogen-131 I used by McFarlane and co-workers seems the most satisfactory. In four normal subjects the mean value of $\mathrm{C}_{1}$ was 0.77 and the halflife about 3 days, compared with our means of 0.82 and 3.36 days. Their mean values of 0.31 per day for fractional catabolic rate and $41.2 \mathrm{mg}$ per $\mathrm{kg}$ per day for catabolic flux of fibrinogen are, however, rather higher than our values of 0.25 and $31.3 \mathrm{mg}$ per $\mathrm{kg}$ per day. Amris and Amris (20) reported studies of fibrinogen- ${ }^{131}$ I metabolism in three subjects suffering from neurosis or intervertebral disc prolapse that agree closely with ours.

The present study does not provide clues as to how fibrinogen is catabolized, namely, whether it is broken down directly or after fibrin formation, or by both paths. However, mathematical considerations described below provide some information. Elsewhere (6) the fibrinogen system is described by six differential equations, but when assumed that the fibrin- ${ }^{131} \mathrm{I}[\mathrm{w}(\mathrm{t})]$ and the fibrinogen- ${ }^{131}$ I at the catabolic site $[\mathrm{v}(\mathrm{t})]$ were negligibly small or nonexistent, or their respective fractional catabolic rates $j_{5}$ and $k_{6}$ were very large if both $\mathrm{w}(\mathrm{t})$ and $\mathrm{v}(\mathrm{t})$ were present in significant amounts, the fibrinogen system can be described by four differential equations. The validity of these assumptions may be tested by comparing the observed values of the breakdown products of fibrinogen-125I ( $z)$, the cumulative radioactivities excreted in the urine $(u)$, and the extravascular fibrinogen- ${ }^{125} \mathrm{I}(y)$ obtained from $y=1-x-\mathrm{z}$ $-\mathfrak{u}$ with those values predicted by the four differential equations describing the simplified model. The analysis showed that the observed values of $z$ and $y$ agreed closely with those predicted by the equations, and as shown in Figure 3 the agreement between the observed and predicted values of $u$ was excellent, justifying the assumptions made above. Particular attention should be paid to the close agreement between the observed and predicted values of $\mathfrak{u}$, since had there been significant 


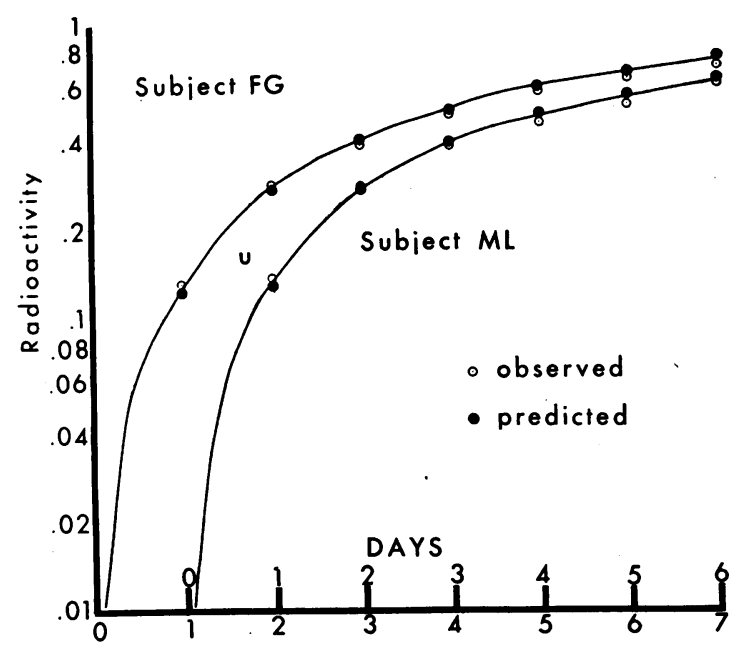

Fig. 3. Comparison of OBSERVEd and PREDICTEd VALUES OF $U$ IN SUBJECTS FG AND ML. $\mathfrak{u}$ is the cumulative radioactivities excreted in the urine. For further details see text.

amounts of fibrin-125I formation with a slow catabolic rate there should be a delay in their excretion in the urine compared with the predicted values of $\mathfrak{u}$. Thus, these results do indicate that in healthy individuals fibrinogen is either catabolized directly with insignificant fibrin formation, or, if significant amounts of fibrin are formed, these are broken down very rapidly. Also, the close agreement between the observed and predicted values of $z, y$, and $u$ implies that fibrinogen is broken down intravascularly, since in this model fibrinogen is assumed to be catabolized in the vascular compartment, although it does not eliminate the possibility that it may be broken down at sites in rapid exchange with the vascular compartment. This thesis is particularly strengthened in view of the close agreement between the observed and predicted values of $\mathfrak{u}$, for if the catabolism of fibrinogen- ${ }^{125}$ I had taken place in extravascular compartments slowly exchanging with the plasma, the urinary excretion of the breakdown products of fibrinogen- ${ }^{125} \mathrm{I}$ would have been significantly delayed compared with the predicted values of $u$.

\section{Summary}

Fibrinogen averaging $96 \%$ clottability wás prepared from the subjects' own plasma by repeated salt fractionation with $\frac{1}{4}$ saturated ammonium sulfate and labeled with ${ }^{125} \mathrm{I}$ in a ratio of 0.5 or less atoms iodine per molecule of fibrinogen. With this preparation, studies were made of the metabolism and distribution of fibrinogen in 12 healthy male subjects.

The results of the present studies were as follows: The average value for the plasma volume was $35.6 \pm 3.5 \mathrm{ml}$ per $\mathrm{kg}$; for the plasma fibrinogen concentration, $360 \pm 50 \mathrm{mg}$ per $100 \mathrm{ml}$; for the intravascular fibrinogen, $127 \pm 17 \mathrm{mg}$ per $\mathrm{kg}$; for the interstitial fibrinogen, $24.0 \pm 6.8 \mathrm{mg}$ per $\mathrm{kg}$; for the slower half-life of fibrinogen- ${ }^{125} \mathrm{I}$, $3.36 \pm 0.25$ days; for the transcapillary transfer rate of fibrinogen, $69.0 \pm 35.3 \mathrm{mg}$ per $\mathrm{kg}$ per day; and for the catabolic rate of fibrinogen, $31.3 \pm 5.0$ mg per $\mathrm{kg}$ per day.

These studies are compared with those of previous investigators, and criteria of satisfactory behavior of fibrinogen-131 I are examined. The kinetic data indicate that in healthy individuals fibrinogen is either catabolized directly with insignificant fibrin formation or that if significant amounts of fibrin are formed these are broken down almost instantaneously. Also it was shown that fibrinogen is catabolized intravascularly or at sites in rapid exchange with the vascular compartment.

\section{Acknowledgments}

My sincere thanks are due to Dr. E. B. Reeve for his unfailing aid and encouragement and to Laurie Stuart for her technical assistance.

\section{References}

1. Madden, R. E., and R. G. Gould. Turnover rate of plasma fibrinogen. Fed. Proc. 1952, 11, 252.

2. Volwiler, W., P. D. Goldsworthy, M. P. MacMartin, P. A. Wood, I. R. Mackay, and K. Fremont-Smith. Biosynthetic determination with radioactive sulfur of turn-over rates of various plasma proteins in normal and cirrhotic man. J. clin. Invest. 1955, 34, 1126.

3. McFarlane, A. S., D. Todd, and S. Cromwell. Fibrinogen catabolism in humans. Clin. Sci. 1964, 26, 415.

4. Atencio, A. C., D. C. Burdick, and E. B. Reeve. An accurate isotope dilution method for measuring plasma fibrinogen. J. Lab. clin. Med. 1965, 66, 137.

5. McFarlane, A. S. In vivo behavior of $\mathrm{I}^{131}$-fibrinogen. J. clin. Invest. 1963, 42, 346.

6. Atencio, A. C., H. R. Bailey, and E. B. Reeve. Studies on the metabolism and distribution of fibrinogen in young and older rabbits. I. Methods and models. J. Lab. clin. Med. 1965, 66, 1. 
7. McFarlane, A. S. Efficient tracer-labelling of proteins with iodine. Nature (Lond.) 1958, 182, 53.

8. Takeda, Y., and E. B. Reeve. Distribution and excretion of $\mathrm{I}^{131}$-iodide in men on pharmacologic doses of iodides. J. Lab. clin. Med. 1962, 60, 944.

9. Reeve, E. B., and H. R. Bailey. Mathematical models describing the distribution of $\mathrm{I}^{131}$-albumin in man. J. Lab. clin. Med. 1962, 60, 923.

10. Takeda, Y., and E. B. Reeve. Studies of the metabolism and distribution of albumin with autologous $\mathrm{I}^{131}$-albumin in healthy men. J. Lab. clin. Med. 1962, 61, 183.

11. Moore, R. H., and R. K. Zeigler. The Solution of the General Least Squares Problem with Special Reference to High Speed Computers, 15th ed. Los Alamos, Los Alamos Scientific Laboratory, 1962, p. 1.

12. Takeda, Y., I. C. Plough, and E. B. Reeve. Excretion of the radioactive catabolic end products of $\mathrm{I}^{181}$-albumin in human sweat. J. clin. Invest. 1960, 39, 1034.

13. Jacobson, K. Studies on the determination of fibrinogen in human blood plasma. Scand. J. clin. Lab. Invest. (suppl. 14). 1955, 14, 7.
14. Atencio, A. C., and E. B. Reeve. Studies on the metabolism and distribution of fibrinogen in young and older rabbits. II. Results. J. Lab. clin. Med. 1965, 66, 20.

15. Berson, S. A., R. S. Yalow, S. S. Schreiber, and J. Post. Tracer experiments with $\mathrm{I}^{131}$ labeled human serum albumin: distribution and degradation studies. J. clin. Invest. 1953, 32, 746.

16. Baker, C. H., and H. D. Wycoff. Time-concentration curves and dilution spaces of $\mathrm{T}-1824$ and $\mathrm{I}^{181}$ labeled proteins in dogs. Amer. J. Physiol. 1961, 201, 1159.

17. Gitlin, D., and W. H. Borges. Studies on metabolism of fibrinogen in two patients with congenital afibrinogenemia. Blood 1953, 8, 679.

18. Christensen, L. K. The turnover of plasma fibrinogen. Acta med. scand. 1958, 162, 407.

19. Hammond, J. D. S., and D. Verel. Observations on the distribution and biological half-life of human fibrinogen. Brit. J. Haemat. 1959, 5, 431.

20. Amris, A., and C. J. Amris. Turnover and distribution of ${ }^{131}$ iodine-labelled human fibrinogen. Thrombos. Diathes. haemorrh. (Stuttg.) 1964, 11, 404. 